\title{
The Effect of Locus of Control, Time Budget Pressure, and Professional Commitment on Dysfunctional Audit Behaviour
}

\author{
Christian Mangiwa ${ }^{1}$, Agus Bandang ${ }^{1}$, Hamka Ridwan², Muhammad Ashari ${ }^{1}$, Maxyanus Taruk Lobo'1 \\ Hasanuddin University, Indonesia \\ Financial and Development Supervisory Bodies, Gorontalo Province-Indonesia \\ hamkaridwan@gmail.com
}

\begin{abstract}
Abstrac: This study aims to determine the effect of locus of control, time budget pressure, and professional commitment on dysfunctional audit behaviour. The data used in this research is the primary data. Data was collected by using a survey method by distributing questionnaires to the auditors of Representative Supreme Audit Board in South Sulawesi Province. The method of analysis that was used to test the hypothesis is multiple linear regression with software Statistical Package for Social Science (SPSS) version 23. The analysis is based on data from 55 respondents who have completed all the statements and questionnaires. The results of this study show that (1) external locus of control and time budget pressure has a positive effect on dysfunctional audit behaviour and (2) professional commitment has a negative effect on dysfunctional audit behaviour.
\end{abstract}

Keywords: Dysfunctional audit behaviour, external locus of control, time budget pressure, professional commitment

\section{Introduction}

The examination under Law No. 15 of 2004 is a process of identifying problems, analyzes, and evaluations conducted directly, objectively and professionally based on audit standards, to assess the truth, accuracy, credibility, and information on the management and accountability of state finances. One institution responsible for state finance is the Supreme Audit Board of the Republic of Indonesia (as known BPK RI) in Constitution of the Republic of Indonesia in 1945 article 23E. As an external auditor of the government, BPK's auditors should conduct an audit under the State Auditing Standards (SPKN), as set forth in article 1 clause 1 of Law no. 15 of 2004 so that the results of BPK's audit can be more qualified. This State Audit Standards is stipulated by BPK's Regulation Number 01 of 2007 as mandated by the existing Law, such as Article 5 of Law Number 15 of 2004 regarding Audit of State Financial Management and Accountability and Article 9 clause 1 letter e of Law Number 15 of 2006 about the State Audit Board. The State Auditing Standards contain the professional requirements of the auditor, the quality of audit execution and the professional inspection reporting that requirements for inspectors and their organizations in carrying out the audit of state financial management and accountability (the Supreme Audit Board of the Republic of Indonesia, 2007). In carrying out its duties, BPK's auditors always uphold the basic values (independence, integrity and professionalism) that have been stated in the Strategic Plan as known Renstra BPK 2016-2020. And then, These three basic values are set forth in the BPK mission for 2016-2020, which are (1) examine the management and responsibility of state finances independently and (2) implement an integrity, independent and professional organizational governance. Thus, it is expected that the BPK audit report can be trusted and free from the interests of certain parties.

In the fact, BPK's auditors often make deviations to the basic values of BPK, which cause the quality of audit reports to be less trusted by the public. This behavior is thought to be the result of bad personal characteristics that an auditor has. The disclosure of several corruption cases that have dragged several BPK's auditors are evidence that BPK's auditors in performing their duties are particularly vulnerable to dysfunctional behavior. Based on the news from Tempo.co November 21st, 2005 edition, it is known that there are four auditors of BPK who are designated as suspects of corruption case of eternal funds in the Ministry of Religious Affairs. They are Khairiansyah Salman; Hariyanto; Tohari Sawanto; And Mukrom A'sad. In 2010, Tempo.co September 20th, 2010 edition also reported on Suharto and Enang Hernawan (both of them are auditors of Representative Supreme Audit Board in West Java) who were charged with taking a bribe of 400 million rupiah from Bekasi City Government employees to provide unqualified opinion for the financial statements of Bekasi in 2009. In addition, in Tempo.co edition of June 14th, 2016 it was reported that the Corruption Eradication Commission stated there is no evidence to suggest that the purchase of 
Sumber Waras Foundation leads to corruption. This is in contrast to the results of audits that have been conducted by the BPK to the transaction which states that the Government of DKI Jakarta has cost the state of 191.3 billion rupiah. Chairman of the Legal Commission of the House of people's Representatives, Bambang Soesatyo, in Tempo.co June 15th, 2016 edition firmly questioned the independence of BPK in conducting audits of Sumber Waras investigation, so he suggested replacement of the Chairman of BPK. From these cases, it can be concluded that unprofessional and unindependent attitudes of some BPK's auditors resulted in poor quality of audit. Irawati et al. (2005) states that any form of manipulation or dishonesty in the audit, will eventually lead to behavioral aberrations.

Dysfunctional audit behavior is a distorted behavior performed by an auditor in the form of manipulation, fraud or irregularity to audit standards (Sampetoding, 2014). Dysfunctional behavior that will be discussed in this study consists of two things, namely audit quality reduction which is a dysfunctional behavior that is considered to reduce the quality of audit directly, and underreporting of time that is considered to reduce audit quality indirectly. This study focuses on auditor dysfunctional behavior (audit quality reduction behavior and underreporting of time) which is influenced by dispositional attributions and internal attributions. Internal causes tended to refer to aspects of individual behavior, that is something that has existed in a person such as a personal nature, self-perception, ability, and motivation. While external causes more refers to the environment that affects one's behavior, such as social conditions, social values, and views of society. Internal factors affecting auditor dysfunctional behavior are locus of control and professional commitment (Silaban, 2009; Alkautsar, 2014). While external factors that influence the dysfunctional behavior of auditors are time budget pressures (Hardyan, 2013; Silaban, 2009; Sososutikno, 2003). The initial concept of a locus of control was introduced by Rotter which outlines that every individual has control over the various factors that occur in his or her life. This locus of control can be both internal and external. The internal locus of control is a personality in which a person believes that he or she controls what happens to him or her. Individuals who have internal locus of control have a high work ethic, resilient to face all kinds of difficulties both in their lives and in their work (Damanik, 2015: 57). In contrast, the external locus of control is a belief that what happens to his or her life is controlled by external forces such as luck and fortune. If individuals with external locus of contol make something wrong, so they tend to blame the surrounding environment that causes it (Damanik, 2015: 59). Several previous studies predicted that external locus of control can affect positively to dysfunctional audit behavior (Sampetoding, 2014; Alkautsar, 2014; Silaban, 2009; Donnelly et al., 2003).

Budget pressure is an obstacle to the auditor in the performance of its duties, where resources such as the time allocated for the implementation of the duty of an auditor is limited (Marfuah, 2011). When the auditor faces time budget pressures, he will try in any way to achieve a predetermined time budget, one way is to do dysfunctional behavior. Previous studies have predicted that time budget pressures have a positive relationship to dysfunctional behavior of auditors (Sari et al., 2016; Silaban, 2009; Sososutikno, 2003). Professional commitment is a personal characteristic of the individual where there is loyalty to the profession so he or she receives and upholds the values and goals of the profession (Silaban, 2009). Professional commitment has now developed into a multidimensional professional commitment, which consists of affective professional commitment, continuous professional commitment, and normative professional commitment. Previous research predicts that the commitment will negatively affect the auditor dysfunctional behavior (Sampetoding, 2014; Wijayanti, 2007; Donnelly et al., 2003).

This research is a replication of the research of Silaban (2009) and Sampetoding (2014) on dysfunctional behavior of auditors where the difference things are the independent variables and the object of research that used. Sampetoding (2014) in her research using unidimensional variable organizational commitment, while in this study using multidimensional professional commitment (affective, continuous, and normative). Another difference is in the object of research used, where the previous research used the Public Accounting Firm (Silaban, 2009) and the State Development Audit Board (Sampetoding, 2014), while the object in this study is the Supreme Audit Board. The reason why researchers are interested in conducting research whose population focuses on auditors working for the Supreme Audit Board because auditors at the Supreme Audit Board have an important role in examining the management and responsibility of the state finances, and in performing those duties the Supreme Audit Board is required to uphold Three basic values of independence, integrity, and professionalism. In addition to these reasons, the disclosure of cases involving auditors of the 
Supreme Audit Board indicates that auditors of the Supreme Audit Board are highly vulnerable to dysfunctional behavior and this is contrary to the three basic values held by the auditors of the Supreme Audit Board of the Republic of Indonesia. Therefore, the researcher will try to study "The Effect of Locus of Control, Time Budget Pressure, and Professional Commitment on Dysfunctional Audit Behaviour (Survey on the Representative Supreme Audit Board in South Sulawesi Province".

\section{Literature Review}

Theory of Change of Attitude: This theory of attitude change was introduced by Carl Hovland in the early 1950s. This theory provides an explanation of how a person's attitude is formed and how that attitude can change through the communication process and how that attitude can affect one's actions or behavior. The theory of change in attitude, among others, states that a person will experience discomfort in him when he is faced with new information that is contrary to his belief (Kamil, 2013). Based on this theory, the auditor will experience discomfort in himself when having a mismatch of demands against a pressure or conflicting circumstances (demands on the completion of the work when the resources are very limited). In such circumstances, the auditor will attempt to eliminate any such discrepancies possible by prioritizing and eliminating something that is considered less important (Fatimah, 2012).

Motivation Theory $\mathbf{X}$ and Y: Motivation talks about the direction of behavior, the level of how much effort the individual takes after a certain action. In addition, motivation also talks about the survival of a person's behavior or how long he or she behaves in a certain way (Hehanusa, 2013). Theory X and $Y$ is a theory developed by McGregor, in which he classifies human beings into two types: human beings tend to behave negatively called human type $X$, and humans tend to behave positively called human type $Y$ (Siagian, 2004). In the $\mathrm{X}$ and $\mathrm{Y}$ motivation theories found by Mc Gregor, individuals of type $\mathrm{X}$ are individuals who have an external locus of control. Such individuals do not like responsibility and must be compelled to excel, and must be motivated by their environment, whereas individuals of type Y are individuals with internal locus of control. Individuals like these love their work, creative, try to be responsible, and can direct theirselves with a specific target. Researchers use this theory because an auditor will accept and then perform dysfunctional behavior of the auditor, mainly due to internal factors such as personal characteristics (X or Y).

Attribution Theory: Attribution theory studies the process by which a person interprets an event, reason, or cause of its behavior. This theory was developed by Fritz Heider, he stated that one's behavior is determined by a combination of internal forces, ie factors that come from within a person, such as ability or effort, and external force, factors that come from outside, such as difficulties in work and luck (Lubis, 2010). The causes of behavior in social perception are known as dispositional attribution and situational attribution or internal and external causes (Robbins et al., 2014). Disposition attribution refers to a behavior that is believed to be influenced by an individual's personal control. Situational attribution or external causes refers to the behavior of external causes, ie the individual is perceived to have been forced to behave thus by the situation.

Locus of Control: One of the personal characteristics that distinguish individuals with one another is the control center called locus of control. Locus of control is a concept developed by Julian B. Rotter where it is expressed that each individual builds expectations about their success depending on their behavior or on things outside themselves (Alkautsar, 2014: 35-36). Gitosudarmo \& Sudita (2008: 21) suggests that the locus of control relates to the extent to which a person has a belief that what they do will affect the reward he or she will receive. Damanik (2015: 56) explains that there are four basic concepts of Julian B. Rotter regarding locus of control as follows

- Potential behavior that is every possibility that relative appear in certain situations related to desired outcome in one's life.

- Expectation is a possibility of events occurring and experiencing by a person.

- The value of the reinforcing element, which is the choice of possible reinforcement of the results of several other amplifiers that appear in similar situations

- Psychological atmosphere, namely the form of stimuli both internally and externally that increase or decrease expectations of the emergence of results that are expected. 
The locus of control is divided into two: the internal locus of control and the external locus of control. Rotter (1990: 489) defines an internal locus of control as "degree to which persons expect that a reinforcement or an outcome of their behavior is contingent on their own behavior or personal characteristics". An internal control personality is a personality in which a person believes that he controls what happens to him. Internal locus of control reflects the level of confidence that the good and bad events that occur are caused by his own actions. while the external locus of control is defined as "the degree to which persons expect that the reinforcement or outcome is a function of chance, luck, or fate, is under the control of the powerful others, or is simply unpredictable" (Rotter, 1990: 489). The personality of external control is one's belief that what happens to it is controlled by external forces such as luck and fortune. If individuals with external locus of contol experience failure, then they tend to blame the surrounding environment that causes it. They feel inadequate and less fortunate that they have no hope of correcting the failure (Damanik, 2015: 59). The locus of control used in this study is an external locus of control measured by an instrument consisting of sixteen (16) question items with the following indicators: (1) the individual belief that the power of others, destiny and opportunity are the main factors affect what is experienced, and this indicator; (2) have poor control over their own behaviors; (3) tend to be influenced by others elaborated; (4) are often not convinced that the work they do can be successfully; and (5) less actively seeking information and knowledge related to the situation faced.

Time Budget Pressure: Time budget pressure is a condition in which the auditor is required to perform the efficiency on time budget that has been prepared and there are restrictions on time in a very tight budget. Audit time budget pressure is actually a normal situation in the auditor's work environment (Sari et al., 2016: 8). Margheim et al. (2005: 24) explains that "Budget related time pressure can only occur when the budgeted amount of time is less than the total available time and the auditor has the ability to respond to the pressure by completing the work on their personal time and underreporting the amount of time spent on the audit task ". Budget audit time becomes one of the main factors that determine the success of auditors in carrying out the audit assignment. Hardyan (2013: 19) explains that "the audit time budget also becomes a benchmark in the evaluation of the auditor staff, each auditor has a target time budget to be met and if there is a budget overtime then the evaluation of the auditor is negative. When faced with time budget pressure, the auditor will respond in two ways: functional responses and dysfunctional responses. The functional type is the behavior of the auditor to work better and to use the time as well as possible. Meanwhile, the dysfunctional type is the behavior of the auditor which makes the quality of audit decrease (Setyorini, 2011: 15).

Time budget pressure consistently associated with dysfunctional behavior is a direct and serious threat to audit quality. Time pressure is a condition in which the auditor is required to consider the economic factor (time and cost) in determining the amount and compliance of audit evidence collected. Thus, the auditor feels pressured in completing the audit process because of unbalance between task, time, and cost received. This resulted in auditors tend to choose dysfunctional behavior in completing the audit process in order to complete the task on time (Hartati, 2012). The timely completion of the audit in addition to meeting client demand is also one of the keys to successful auditor careers in the future. Therefore, there is always pressure for the auditor to complete the audit within the budgeted time. Auditors who complete the task beyond the normal time that has been budgeted tend to be judged to have poor performance by superiors or difficult to get promotion. The criteria for obtaining good rankings are the achievement of the time budget (Lestari, 2010: 17). In order to keep the time budget set, it is possible for the auditor to commit such deviant acts as a waiver of audit procedures and even termination of audit procedures. The greater the time budget pressure perceived, the greater the deviation will be done. Time budget pressure is measured by an instrument consisting of six (6) question items, with the following indicators: (1) the tightness of the time budget and (2) the time budget constraint.

Professional Commitment: Auditor commitment to his profession is one of the determining factors or has a strong influence on his conduct in conducting the audit. Professional commitment is a development of a more established concept of organizational commitment. Professional Commitment is based on the premise that individuals form a loyalty to the profession during the socialization process when the profession instills professional values and norms (Silaban, 2009). Alkautsar (2014) states that "the commitment to the profession auditor is an individual auditor characterized by loyalty and fidelity of individual auditors on the purpose and values of the profession." Aranya et al. (1981: 271) states that Profesional commitment is the 
relative strenght of their identification with, and involvement in, their profession. Commitment may indicate (1) the belief in, and acceptance of, the goals and values of the profession, (2) a willingness to exert considerable effort on behalf of the profession, and (3) a definite desire to maintain membership in the profession. Commitment has become one of the important elements in the world of work. One of the factors that can affect one's success and performance in work is commitment. The underlying reason for high commitment to every profession is the need for public confidence in the quality of services provided by the profession regardless of the individual. Public confidence in the quality of professional services will increase, if the profession embodies high standards of work and behavior and meets all needs. Understanding this professional commitment is essential to create a conducive working environment so that the company can run efficiently and effectively (Damanik, 2015: 66-67).

Professional commitment is initially seen as a concept that is unidimensional or has a single dimension. However, in line with the development of research results, the concept of professional commitment has also evolved into a multidimensional concept. There are three conceptual component models of commitment introduced by Meyer and Allen (Luthans, 2011: 148; Meyer et al., 1991) consisting of affective professional commitment, continuance professional commitment, and commitment professional normative (normative professional commitment). Affective professional commitment relates to the extent to which individuals "want to be in a profession" (Meyer et al., 1991; Silaban, 2009). "Affective professional commitment refers to identification with, involvement in, and emotional attachment to the profession" (Bagraim, 2003). Affective professional commitment is an individual's emotional attachment to his profession based on the identification of professional values and goals and a desire to help the profession achieve those goals (Meyer et al., 1991; Silaban 2009). For example those with strong affective professional commitment will follow developments in their profession, subscribe to journals, attend professional meetings, and participate in their professional associations (Bagraim, 2003).

Continuous professional commitment relates to the extent to which individuals "remain" in a profession (Meyer et al., 1991). Continuous professional commitment is a form of one's commitment to the profession based on consideration of the costs incurred if one leaves the profession (Bagraim, 2003; Silaban, 2009). Employees with strong continuous commitment try to stay in their profession because they realize they will have a big loss when they get out of the profession (Bagraim, 2003). Normative professional commitment relates to the interrelationship of individuals with a profession because it feels an obligation or responsibility to remain in a profession. Employees with strong normative professional commitment will retain their membership in the profession because they feel that it must be done. Normative professional commitment may develop due to socialization in its effective profession or because of its sacrifices to engage in the profession (Bagraim, 2003). Professional commitment is measured by an instrument consisting of eighteen (18) question items with the following indicators: (1) affective professional commitment; (2) continuous professional commitment; and (3) normative professional commitment.

Auditor Dysfunctional Behavior: Dysfunctional behavior is an unethical action because it will reduce the quality of audit directly or indirectly. Donnelly et al. (2003: 4) says that "In an auditing context, manipulation or deception will manifest itself in the form of behavioral dysfunctioal audit. These behaviors are means for the auditors to manipulate the audit process in order to achieve the individual's performance objective. While according to Sari et al. (2016: 8) "Audit dysfunctional behavior is the behavior of auditors in the audit process that is not in accordance with the audit program that has been established or deviate from established standards". The implications of this dysfunctional behavior are that auditors tend to produce poorly qualified audits and may mislead the users of the report (Sitanggang, 2007). From the above explanation can be concluded that the dysfunctional behavior of auditors is a deviant act done by the auditor by manipulating or cheating on the audit process to achieve his personal goals. In outline, the dysfunctional behavior of auditors is divided into 2 ie, audit quality reduction behavior and underreporting of time. Both of these behaviors are categorized as unethical conductors because the auditor manipulates the performance reports imposed on them by reducing the work that should be done and reporting the audit time shorter than the actual time used (Silaban, 2009). Auditor dysfunctional behavior is measured by an instrument consisting of thirteen (13) question items with the following indicators: (1) the audit quality reduction behavior and (2) underreporting of time. 
Locus of External Control and Dysfunctional Audit Behavior: Locus of control is a personal characteristic in which each individual will build expectations about how certain he or she is capable of controlling what will happen to him (Tanjung, 2013). Individuals who have external locus of control will perceive success or failure from luck and fate. Theory of $\mathrm{X}$ and $\mathrm{Y}$ it is explained that an individual possessing an external locus of control (type X) will have less effort to seek information in problem solving because it considers that external factors are the main cause of success or failure, so that when he experiences work stress, It will strengthen the likelihood of the occurrence of dysfunctional behavior. Previous research has proven that external locus of control will positively affect the auditor's dysfunctional behavior (Donnelly et al., 2003). Another study conducted by Silaban (2009) shows a positive and significant influence of external locus of control on dysfunctional audit behavior (audit quality reduction and underreporting of time). In addition Alkautsar's study (2014) proved a positive relationship of locus of control to dysfunctional audit behavior. Research conducted by Sampetoding (2014) also proves a positive influence of the locus of control externally on dysfunctional behavior of auditors.

\section{H1: The external locus of control positively affects the dysfunctional audit behavior.}

Budget Time Pressure and Dysfunctional Audit Behavior: Audit time budget as a benchmark for the evaluation of the auditor's staff. If they can work within a given time budget, it will have a positive impact on their future career prospects. A tight time budget will cause the auditor to be under pressure in the conduct of their audit. According to the theory of attitude change, the auditor will experience the discomfort of being required to complete the job, while the existing resources such as the time is very limited. Such circumstances will force the auditor to perform deviant (dysfunctional) actions in order to reach the prescribed time budget (Hardyan, 2013). This is in accordance with the explanation of situational attribution which states that the auditor is considered to have dysfunctional behaviour caused by the situation that is the demand for the achievement of the time budget. Previous research has shown that time budget pressure has a positive relationship to dysfunctional audit behavior (Sososutikno: 2003). Research conducted by Sari et al. (2016) also proved that time budget pressure has a positive and significant effect on dysfunctional audit behavior. In addition, according to Silaban's study (2009) there has been a positive and significant impact of perceived time budget pressure on dysfunctional audit behavior (audit quality reduction and underreporting of time). H2: Time budget pressure positively affects dysfunctional audit behavior.

Professional Commitment and Auditor Dysfunctional Behavior: Professional commitment is a development of a more established concept of organizational commitment. Professional commitment can be interpreted as an individual characteristic related to loyalty to the purpose and values of his profession (Alkautsar, 2014). In attribution theory, professional commitment can be classified as a disposition attribution that is the internal cause which causes a person's behavior. A high professional commitment will lead to the auditor toward behavior in the public interest as well as away from the potentially damaging behavior of the profession. Whereas, auditors with lower professional commitment will tend to behave dysfunctionally (Lord and Dezoort, 2001: 220). Previous research has shown that there is a negative relationship between commitment to dysfunctional behavior (Donnelly et al., 2003). Research conducted by Sampetoding (2014) shows that commitment is negatively related to dysfunctional behavior of auditing. In addition, research conducted by Wijayanti (2007) shows a negative influence of commitment to dysfunctional behavior of auditors.

H3: Professional commitment negatively affects dysfunctional audit behavior.

\section{Methodology}

Participants and Data Collection Procedure: The population in this study is BPK's Auditors of Representative Supreme Audit Board in South Sulawesi Province. Auditors are divided by the work area of the entity, consisting of Sub-Auditorat Sulsel I as many as 34 people, Sub-Auditorate South Sulawesi II as many as 29 people and Sub Auditorat South Sulawesi III as many as 30 people. Thus, the aggregate amount of auditors of the Representative Supreme Audit Board in South Sulawesi Province as the population in this study is 93 people. Data colletion techniques conducted in this study is using questionnaires that were delivered to auditors of the Representative Supreme Audit Board in South Sulawesi Province. 
Hypothesis Testing: The hypothesis is a basically proportion or response that is often used as a basis for making decisions or solutions to problems. Before tested, the data must first be quantized. Testing statistical hypotheses is a procedure that allows decisions to be made which is to reject or accept hypotheses from data being tested (Sunyoto, 2011: 93). In this study, the analysis to be used is the analysis with multiple linear regression. The equation is as follows.

$\mathrm{Y}=\alpha+\beta 1 \mathrm{X} 1+\beta 2 \mathrm{X} 2+\beta 3 \mathrm{X} 3+\dot{\varepsilon}$

Description: $\mathrm{Y}=$ auditor dysfunctional behavior

$\mathrm{A}=$ constants

$\mathrm{X} 1=$ external locus of control

$\mathrm{X} 2=$ time budget pressure

$\mathrm{X} 3=$ professional commitment

$B 1, \beta 2, \beta 3=$ regression coefficients to be calculated

$\mathrm{E}=$ error factor or error term

The hypothesis test is done by statistic test about the affect of locus of control, time budget pressure and professional commitment to dysfunctional behavior of auditor in BPK Representative of south sulawesi province. This tatistic test used two forms of hypothesis testing that is partial with $t$ test (to see the partially influence of each variable to Dysfunctional behavior of auditor in BPK Representative of South Sulawesi) and simultaneously with $\mathrm{F}$ test (to see the overall effect of external locus of control, time budget pressure, and professional commitment to dysfunctional audit behavior in BPK Representative of South Sulawesi).

Individual Parameter Significance Test ( $t$ test): The t test basically indicates how far the influence of an individual explanatory/independent variable in explaining the dependent variable. The zero hypothesis (Ho) to be tested is whether a parameter is equal to zero, or:

Ho: $\beta 1 \beta 2 \beta 3=0$

That is, whether an independent variable is not a significant explanation of the dependent variable. The alternative hypothesis (Ha) parameter of a variable is not equal to zero, or

Ha: $\beta 1 \beta 2 \beta 3 \neq 0$

That is, the variable is a significant explanation of the dependent variable.

Simultaneous Significance Test (F Test): This test involves the three independent variables (external locus of control, time budget pressure, and professional commitment) on the dependent variable (dysfunctional behavior of the auditor) in examining the presence or absence of influence simultaneously. Testing simultaneously using $\mathrm{F}$ distribution, that is comparing between $\mathrm{F}$ arithmetic with $\mathrm{F}$ table.

- Ho: $\beta 1 \beta 2 \beta 3=0$, meaning external locus of control, time budget pressure and professional commitment are insignificant or have no effect simultaneously on dysfunctional behavior of auditor BPK Representative of South Sulawesi province.

- Ha: $\beta 1 \beta 2 \beta 3 \neq 0$, meaning external locus of control, time budget pressure and professional commitment affect simultaneously to dysfunctional behavior of auditor BPK Representative of South Sulawesi Province.

\section{Results}

\section{Assumptions Of The Classical Model Test}

Normality Test: Normality test aims to determine whether each variable, whether the independent variable or the dependent variable is normally distributed or not. A good regression model is data that has a normal or near normal distribution. Normality test in this research using approach of Normal Probability Plot (P-Plot). Based on the normal probability plot, it can be concluded that the regression model is feasible to use because it meets the assumption of normality. This is evidenced by the occurrence of the spread of data (dots) around the regression line (diagonal line).

Multicollinearity Test: This classical assumption test is used for multiple regression analysis at least consisting of two independent variables, association level (closeness) or ( $r$ ) relationship. This test aims to 
determine whether in a multiple linear regression model there is correlation between variables. A good multiple linear regression model is one that does not have multicollinearity. One way to test multicollinearity is looking at the tolerance and variance inflation factor (VIF). The common cut-off value used to indicate the presence of multicollonierity is the tolerance value $<0.10$ or equal to the VIF value $>10$. Based on the multicollinearity test, it was found that no independent variable has a tolerance value of less than 0.10 , as well as with VIF value in each independent variable no more than 10. Thus, it can be concluded that there is no multicollinearity in this study, so one of the requirements of multiple regression tests have been fulfilled.

Heteroscedasticity test: Heteroscedasticity test is performed to see the same or not of the variance of the residual from one observation with another observation. If the residual has the same variance, it is called homoscedasticity but there is heteroscedasticity if the variance is not same. A good regression equation is homoscedasticity or no heteroscedasticity. It is said that there is no heteroscedasticity if the points of data processing on scatterplot are spreading below or above the orgin point (zero) on the Y axis and are not having a regular pattern. Based on the scatterplot, it can be seen that the pattern of the dot's spreading is above and below the point orgin (zero) on the $\mathrm{Y}$ axis and does not have a regular pattern. Therefore, it can be concluded that there is no heteroscedasticity in the regression model used. Thus the assumption of non heteroscedasticity is fulfilled.

Hypothesis Testing Results: Data analysis used in this research is multiple linear regression analysis. Multiple linear regression model in this research is used to test independent variable that is external locus of control (X1), time budget pressure (X2), and professional commitment (X3) to dependent variable that is dysfunctional audit behavior (Y).

The general equation of multiple linear regression is as follows.

$\mathrm{Y}=\mathrm{a}+\mathrm{b} 1 \mathrm{X} 1+\mathrm{b} 2 \mathrm{X} 2+\mathrm{b} 3 \mathrm{X} 3+\mathrm{e}$

In the form of multiple linear regression equation, the following results are obtained.

$\mathrm{Y}=8,998+0,322 \mathrm{X} 1+1,147 \mathrm{X} 2-0,098 \times 3+e$

Based on regression model and table 4.7 above, the result of multiple linear regression can be described as follows.

- The multiple linear equations above show the constant value of 8.998. This shows that if the external locus of control variable, time budget pressure, and professional commitment are considered constant, then the dysfunctional audit behavior will increase by 8.998 units.

- The regression coefficient on the external locus of control variable X1 has a constant value of 0.322, this means that if the independent variable increases one unit then the dysfunctional audit behavior variable will increase by 0.322 assuming another variable remains.

- The regression coefficient on the time budget pressure variable (X2) has a constant value of 1.147 this means that when the time budget pressure variable increases one unit then the dysfunctional audit behavior variable will increase by 1.147 with the assumption that other variables remain.

- Regression coefficient on professional commitment variable (X3) has a constant value of -0.098 this means that if the professional commitment variable increased by one unit then the dysfunctional audit behavior variable will decrease by 0.098 assuming other variables remain.

Individual Parameter Significance Test ( $t$ test): $\mathrm{T}$ test is used to determine the influence of each independent variable to the dependent variable (Ghozali, 2016: 171). The following is the result of the test of the significance of individual parameters ( $\mathrm{t}$ test). 
Table 1: Test Results Statistics t Coefficients ${ }^{a}$

\begin{tabular}{|c|c|c|c|c|c|c|c|c|}
\hline \multirow{2}{*}{\multicolumn{2}{|c|}{ Model }} & \multicolumn{2}{|c|}{$\begin{array}{l}\text { Unstandardized } \\
\text { Coefficients }\end{array}$} & \multirow{3}{*}{$\begin{array}{l}\text { Standardized } \\
\text { Coefficients } \\
\text { Beta }\end{array}$} & \multirow[t]{2}{*}{$\mathbf{T}$} & \multirow[t]{2}{*}{ Sig. } & \multirow{2}{*}{\multicolumn{2}{|c|}{$\begin{array}{l}\text { Collinearity } \\
\text { Statistics } \\
\text { Tolerance VIF }\end{array}$}} \\
\hline & & B & Std. Error & & & & & \\
\hline \multirow[t]{4}{*}{1} & (Constant) & 8,998 & 4,108 & & 2,190 & ,033 & & \\
\hline & $\begin{array}{l}\text { External Locus of } \\
\text { Control }\end{array}$ & ,322 & 042 & 462 & 7,596 & ,000 & 685 & 1,460 \\
\hline & Time Budget Pressure & 1,147 & 137 &, 535 & 8,349 & ,000 & 618 & 1,619 \\
\hline & $\begin{array}{l}\text { Professional } \\
\text { Commitment }\end{array}$ &,- 098 & 043 &,- 123 & $-2,250$ & ,029 & ,847 & 1,181 \\
\hline
\end{tabular}

Dependent Variable: Dysfunctional Audit Behaviour

Source: Processed primary data, 2016

Based on the table of test statistical $t$ above, it can be drawn some conclusions related to the results of hypothesis testing, namely.

- External locus of control has a positive and significant effect on dysfunctional audit behavior. This is evidenced from the value of external locus of control (X1) of 7.596 which is greater than t table value of 2.006 and has a significant value of 0.000 smaller than 0.05 . These results suggest that the first hypothesis (H1) which states that the external locus of control positively affects the dysfunctional audit behavior is accepted.

- Time budget pressure has a positive and significant impact on dysfunctional audit behavior. This is evidenced from the value of time budget (X2) computed of 8.349 which is greater than the table value of 2.006 and has a significant value of 0.000 smaller than 0.05 . These results indicate that the second hypothesis (H2) which states that time budget pressure has a positive effect on dysfunctional audit behavior is accepted.

- Professional commitment has a negative and significant influence on dysfunctional audit behavior. This is evidenced from the value of $t$ count of professional commitment variable (X3) by -2,250 which is bigger than $t$ table value equal to 2,006 and has significant value equal to 0,029 smaller than 0,05 . These results indicate that the second hypothesis (H3) which states that professional commitment has a negative effect on dysfunctional audit behavior is accepted.

Simultaneous Significance Test (F Test): The F statistic test is used to find out whether the independent variables simultaneously affect the dependent variable (Ghozali, 2016: 171). The results of simultaneous influence test ( $F$ test) can be seen in the following table.

Table 2: F Test Result

\begin{tabular}{|c|c|c|c|c|c|c|}
\hline \multicolumn{2}{|c|}{ Model } & \multicolumn{2}{|c|}{ Sum of Squares Df } & \multirow{2}{*}{$\begin{array}{l}\text { Mean Square } \\
438,772\end{array}$} & \multirow{2}{*}{$\begin{array}{l}\mathbf{F} \\
114,504\end{array}$} & \multirow{2}{*}{$\frac{\text { Sig. }}{, 000^{\mathrm{b}}}$} \\
\hline 1 & Regression & 1316,317 & 3 & & & \\
\hline & Residual & 195,429 & 51 & 3,832 & & \\
\hline & Total & 1511,745 & 54 & & & \\
\hline
\end{tabular}

a. Dependent Variable: Dysfunctional Audit Behaviour

Predictors: (Constant) External Locus of Control, Time Budget Pressure, Professional Commitment

Source: Processed primary data, 2016

The result of ANOVA or $\mathrm{F}$ test as shown in the table above, obtained the value of $\mathrm{F}$ count of 114,504 and the significance value of 0.000 which is much smaller than 0,05 . Because the significance value is less than 0.05 then all independent variables of external locus of control, time budget pressure, and professional commitment simultaneously affect the dysfunctional audit behavior.

The Effect of External Locus of Control (X1) on Dysfunctional Audit Behaviour (Y): The result of $t$ test between the external locus of control variable and the dysfunctional audit behavior variable shows that the result of $t$ calculate is 7,596 and the regression coefficient is 0,322 which means that the direction is positive to dysfunctional audit behavior and the level of significance indicates the value of 0,000 which means that the 
value is significant because Smaller than 0.05 . Because the level of significance is less than 0.05 or $5 \%$ and the regression coefficient is positive, then the external locus of control positively affects the dysfunctional audit behavior, and it means that the first hypothesis is accepted. The results of this study support the research conducted by Donnelly et al. (2003), Wijayanti (2007), Silaban (2009), Gustati (2012), Hartati (2012), Alkautsar (2014), and Sampetoding (2014). The results of the seven studies show that partially the external locus of control variable positively affects the dysfunctional audit behavior. Positive influence indicates that the external locus of control is in line with the dysfunctional audit behavior, where the higher level of an auditor's external locus of control will increase the auditor's dysfunctional behavior level, and vice versa, if the external locus of control level is low then the auditor's dysfunctional behavior level will also low. The results of this study are supporting the motivational theory of $\mathrm{X}$ and $\mathrm{Y}$ developed by McGroger. Individuals of type $\mathrm{X}$ or individuals with external locus of control are individuals who do not like responsibility (challenge). The mentality of these individuals is not a problem-ready mentality, so when they encounter a problem, they will quickly become irritable, nervous, and dizzy person, and this probrem will reinforce the possibility of dysfunctional behavior.

The Influence of Time Budget Pressure (X2) on Dysfunctional Audit Behavior (Y): The result of t test between time budget pressure with dysfunctional audit behavior shows t count result of 8,349 and regression coefficient yield equal to 1,147. It's meaning that its direction is positive to dysfunctional audit behavior and its significance level indicates value 0.000 which mean this value significant due to smaller than 0.05 . Because the level of significance is less than 0.05 or $5 \%$ and the regression coefficient is positive, then in this case the time budget pressure has a positive effect on the auditor's dysfunctional behavior, so the second hypothesis is accepted. The results of this study are in accordance with research conducted by Silaban (2009), Suprianto (2009), Sososutikno (2003), Tanjung (2013), Sampetoding (2014), and Sari et al. (2016). The result of the those studies stated that partially time budget pressure positively influence to dysfunctional audit behavior. Positive influence shows that time budget pressure is in line with dysfunctional audit behavior. When the level of time budget pressure increase, the level of dysfunctional audit behavior is also increase, and vice versa, if the level of time budget pressure is low, then the level of dysfunctional audit behavior will also be low. This research is also in line with the theory of attitude change developed by Carl Hovland. This theory provides an explanation of how a person's attitude is formed and how that attitude can affect one's behavior or actions. When the auditor is faced with a pressure (the demand for the settlement of work with a very limited time), then the auditor will experience discomfort in him. Such circumstances will compel the auditor to perform dysfunctional behaviors in order to reach a predetermined time budget.

The Influence of Professional Commitment (X3) on Dysfunctional Audit Behavior (Y): The result of t statistic test between professional commitment variable and dysfunctional audit behavior variable shows that the result of $t$ calculation is $-2,250$ and the result of regression coefficient equal to $-0,098$ meaning that its direction is negative to dysfunctional audit behavior and its significance level show value equal to 0,029 which mean value is significant because it's smaller than 0.05 . Since the regression coefficient is negative, then professional commitment negatively affects the auditor's dysfunctional behavior, so the third hypothesis is accepted. The results of this study are in accordance with research conducted by Donnely et al. (2003), Wijayanti (2007), and Sampetoding (2014). The results of these three studies suggest that partially commitment has a negative effect on the detection of fraud. Negative influence indicates that professional commitment is contrary to dysfunctional audit behavior, where the higher commitment of an auditor to his profession will decrease the dysfunctional audit behavior. On the contrary, when the commitment professional is lower, then the dysfunctional audit behavior is higher. This research is also in line with the attribution theory developed by Fritz Heider. Commitment in this theory can be classified as a disposition attribution or an internal factor that causes a person's behavior. Auditors who are highly committed to their profession, will direct him to behave in the public interest and away from deviant acts that are potentially damaging to the profession.

\section{Conclusion}

Based on the results of the analyzes that have been described above, It was concluded that this study succeeded in supporting all the hypotheses filed, the detailed description as follows: 
- The results of this study support the first hypothesis that the external locus of control variable positively affects the dysfunctional audit behavior. This indicates that the auditor who has an external locus of control will see the success or failure of the luck and fate. In X and Y theories developed by McGroger explains that individuals of type $\mathrm{X}$ (individuals with external locus of control) do not like the responsibility (challenge) so that the mentality is not a risk-ready mentality. Therefore, an auditor with an external locus of control will have less effort in finding information in problem solving so that when he / she experiences the stress, it will reinforce the possibility of dysfunctional behavior.

- The results of this study also support the second hypothesis. In this study, time budget pressure variables have a positive effect on dysfunctional audit behavior. The theory of attitude change developed by Carl Hovland explained that the auditor who is experiencing pressure on the time budget will experience discomfort because he is required to reach the budget time set. This circumstance will compel the auditor to perform dysfunctional behaviors in order to reach a predetermined time budget.

- The results of this study support the third hypothesis, that professional commitment variables have a negative effect on dysfunctional audit behavior. In attribution theory, professional commitment can be classified as a disposition attribution or an internal factor that determines a person's behavior. When the auditor has a high professional commitment it will lead the auditor to the behavior with the aim for the public interest and away from deviant behavior that has the potential to damage the profession.

Research Recommendations: In this research still need some repair items to be done on the next research which still have related with the object of similar research, so it can make this research more plenary. As for some suggestions for further research that the sample of respondents should be further expanded to obtain greater representation of the study population under study. This extension can be either the addition of the geographical scope of the respondent and the addition of the quantity of respondents. Further research should also try other instruments besides the questionnaires so that the data obtained can better describe the overall research object. The addition of several other variables used in measuring factors affecting auditor dysfunctional behavior is also recommended.

\section{Reference}

Alkautsar, M. (2014). Locus of Control, Commitment Professional, and Dysfunctional Audit Behaviour. International Journal of Humanities and Management Sciences (IJHMS), 2(3).

Aranya, N., Pollock, J. \& Amernic, J. (1981). An Aximination of Professional Commitment in Public Accounting. Accounting, Organizations and Society, 6(4), 271-280.

Bagraim, J. J. (2003). The Dimensionality of Professional Commitment. SA Journal of Industrial Psychology, $29(2), 6-9$.

Constitution of the Republic of Indonesia Year 1945 Article 23 of the BPK. (2002). Jakarta: The Plenary Session of the People's Consultative Assembly of the Republic of Indonesia.

Damanik, D. (2015). The Influence of Spiritual Emotional Quotieny (SEQ), Locus of Control (LOC), Time Budget Pressure, Morality Auditor, and Professional Commitment to Audit (Case Study in The Regional Goverment on The Inspectorate Dairi. Essay. Medan: Accounting Department of Economic and Business Faculty In University of Northern Sumatra

Donnelly, D. P., Quirin, J. J. \& O’Bryan, D. (2003). Attitudes Toward Dysfunctional Audit Behavior: The Effects of Locus of Control, Organizational Commitment, and Position. The Journal of Applied Business Research, 19(1).

Fahmi, I. (2011). Theory Management, Cases, and Solutions. Bandung: Publisher of alfabeta

Fatimah, A. (2012). Characteristics of Personal Auditors As Anteseden Discoverable Auditor Behavior and Its Effect on Audit Quality Result. Jurnal Manajemen dan Akuntansi, 1(1).

Gitosudarmo, I. \& Sudita, I. N. (2008). Organizational Behavior. Yogyakarta: BPFE-Yogyakarta.

Ghozali, I. (2016). Application of Multivariete Analysis with IBM SPSS Program 23. Semarang: Diponegoro University Publishing Agency. 
Gustati. (2012). Perceptions of the Auditor about the Influence of Locus of Control on the Acceptance of Dysfunctional Audit Behavior (Survey on Auditor BPKP Representative of West Sumatera Province). Jurnal Akuntansi \& Manajemen, 7(2).

Hardyan, B. C. (2013). Dysfunctional Audit Behavior: The Effects of Time Budget Pressure, Leadership Style, and Organizational Commitment. Essay. Semarang: Faculty of Economic and Business, Diponegoro University.

Hartati, N. L. (2012). Effect of Internal and External Characteristics of Auditors on the Acceptance of Dysfunctional Behavior on Audit Procedures. Accounting Analysis Journal, 1(2).

Hehanusa, M. (2013). The Influence of Locus of Control on the Acceptance of Dysfunctional Audit Behavior with Auditor Performance as a Mediation Variable. Cita Ekonomika Jurnal Ekonomi, VII(2).

Irawati, Y., Petronila, T. A. \& Mukhlasin. (2005). Relationship of Characteristics of Personal Auditor To The Level Of Acceptance Of Behavior In Audit. Eightht National Symposium on Accounting page 929-940.

Jatnika, I. (2015). Influence of Burnout Auditor, Organizational Commitment, Moving Intention and Employee Performance on Tolerance of Dysfunctional Behavior of BPK RI Auditor. Thesis. Yogyakarta: Gadjah Mada University.

Kamil, E. N. (2013). Reporting Violence Against Indonesian Journalists and Student Attitudes (Correlational Studies on Relationship Between Violence Against Indonesian Journalists On Metro TV Against Student Attitudes Stik-P). Essay. Medan: Faculty of Social Science and Political Science University of Northern Sumatra.

Lestari, A. P. (2010). Factors Affecting Auditor Behavior In Premature Termination of Audit Procedures. Essay. Semarang: Faculty of Economic, Diponegoro University.

Lord, A. T. \& Dezoort, F. T. (2001). The Impact of Commitment and Moral Reasoning on Auditor's Respons to Social Influence Pressure. Accounting Organizations and Society, 26, 215-235.

Lubis, A. I. (2010). Behavioral Accounting (Edisi 2). Jakarta: Salemba Empat.

Luthans, F. (2011). Organizational Behavior: An Evidence-Based Approach, Twelfth Edition. New York: McGraw-Hill Company.

Marfuah, S. (2011). The Influence of Time Budget Pressure against Auditor Dysfunctional Behavior in Work Stress Theory Perspective. Essay. Semarang: Faculty of Economic Diponegoro University.

Margheim, L., Kelly, T. \& Pattison, D. (2005). An Empirical Analysis of The Effects of Auditor Time Budget Pressure And Time Deadline Pressure. The Journal of Applied Business ResFearch, 21(1).

Meyer, J. P. \& Allen, N. J. (1991). A Three-Component Conceptualization Of Organizational Commitment. Human Resource Management Review, 1(1), 61-89

Robbins, S. P. \& Judge, T. A. (2014). Organization Behaviour Edition 12 Book 1. Jakarta: Salemba Empat.

Rotter, J. B. (1990). Internal Versus External Control of Reinforcement. The American Psychological Association, 45(4).

Sampetoding, P. R. (2014). Relation of Time Budget Pressure, Locus of Control and Organizational Commitment to Dysfunctional Audit Behavior, and How The Dysfunctional Audit Behavior Influence the Audit Quality (Survey on Representative BPKP Government in South Sulawesi Province). Skripsi. Makassar: Faculty of Economic and Business, Hasanuddin University.

Sari, R., Tenriwaru., M. \& Agung, P. (2016). Effect of Time Budget Pressure and Locus of Control of Auditor Dysfunctional Behaviors. Journal of Education and Vocational Research, 7(1).

Setyorini, A. I. (2011). The Influence of Audit Complexity, Time Budget Pressure, and Auditor Experience on Audit Quality with Moderating Variables on Information Systems (Empirical Study of KAP's Auditors in Semarang). Essay. Semarang: Faculty of Economic, Diponegoro University.

Siagian, S. P. (2004). Motivation Theory and Its Application. Jakarta: PT Rineka Cipta.

Silaban, A. (2009). Auditor Dysfunctional Behavior In Implementation of Audit Program. Dissertation. Semarang: Doctoral Program of Economics Diponegoro University..

Sitanggang, A. (2007). Auditor's Acceptance of Dysfunctional Auditing Behavior: A Model Explanation Using the Personal Auditor's Characteristics. Thesis. Semarang: Postgraduate Program in Diponegoro University.

Sososutikno, C. (2003). Time Budget Pressure Relationship With Dysfunctional Behavior And Its Effect on Quality Audit. Sixth National Symposium on Accounting page 1116-1128.

Sugiyono. (2012). Quantitative Research Methods, Qualitative, and R \& D. Bandung: Publisher Alfabeta.

Sunyoto, D. (2013). Accounting Research Methodology. Bandung: Refika Aditama.

Suprianto, E. (2009). Effect of Time Budget Pressure on Auditor Dysfunctional Behavior. JAI, 5(1), 57-65. 
Tanjung, R. (2013). Effect of Personal Auditor's Characteristics and Time Budget Pressure on Auditor Dysfunctional Behavior. Essay. Padang: Faculty of Economic, Padang State University.

Tempo.co. (2005). Khairiansyah Suspects of the Eternal Funders. (online)(http://www.tempo.co/read/news/2005/11/21/05569507/Khairiansyah-TersangkaPenerima-Dana-Abadi-Umat, Accessed on June 21, 2016).

Tempo.co. (2010). Dua Auditor BPK Didakwa Terima Suap. (online)(http://www.tempo.co/read/news/2010/09/20/063279194/Dua-Auditor-BPK-DidakwaTerima-Suap, Accessed on June 21, 2016).

Tempo.co. (2016). KPK: Tidak Ada Korupsi di Pembelian RS Sumber Waras. (online) (https://m.tempo.co/read/news/2016/06/14/063779724/kpk-tidak-ada-korupsi-di-pembelian-rssumber-waras, Accessed on July 26, 2016)

Tempo.co. (2016). Sumber Waras Bebas Korupsi, Bambang Soesatyo: BPK yang Brengsek. (online)(https://m.tempo.co/read/news/2016/06/15/063780034/sumber-waras-bebas-korupsibambang-soesatyo-bpk-yang-brengsek, Accessed on July 26, 2016)

The examination under Law No. 15 of 2004 regarding Audit of Management and Responsibility of State Finances. (2004). Jakarta: Deputy Cabinet for Legal Affairs and Legislation.

The Supreme Audit Board of the Republic of Indonesia. (2007). State Auditing Standards. (Online)(http://www.bpk.go.id/assets/files/storage/2013/12/file_storage_1386233856.pdf, Accessed on June 22, 2016)

The Supreme Audit Board of the Republic of Indonesia. (2016). The strategic plan of 2016-2020. (Online) (http://www.bpk.go.id/page/rencana-strategis, Accessed on June 22, 2016).

The Supreme Audit Board of the Republic of Indonesia. (Without year). Legal Basis. (Online) (http://www.bpk.go.id/page/dasar-hukum, Accessed on June 22, 2016).

Wijayanti, P. (2007). Effect of Personal Auditor's Characteristics on Acceptance of Dysfunctional Audit Behavior. Thesis. Semarang: Postgraduate Program in Diponegoro University. 